\title{
KULEUVEN
}

\section{Information Leakage, Imitation, and the Patent System}

Dirk Czarnitzki and Kristof Van Criekingen

MSI_2108 


\title{
Information Leakage, Imitation, and the Patent System*
}

\author{
Dirk Czarnitzki ${ }^{\mathrm{a}, \mathrm{b}, \mathrm{c}}$ and Kristof Van Criekingen ${ }^{\mathrm{a}, \mathrm{b}, \mathrm{d}}$ \\ a) KU Leuven, Dept. of Management, Strategy and Innovation, Leuven, Belgium \\ b) Centre for R\&D Monitoring (ECOOM) at KU Leuven, Belgium \\ c) Centre for European Economic Research (ZEW), Mannheim, Germany \\ d) Aarhus University, Danish Centre for Studies in Research and Research Policy, Aarhus Denmark
}

This version: August 2021

\begin{abstract}
From a firm's perspective two competing forces are driving the decision to invest in innovation. On the one hand, innovative performance is an important driver of profitability and growth. On the other hand, investments in innovation suffer from negative externalities, i.e. spillovers to other firms, and hence imitation could be induced. To preempt imitation firms may protect their inventions by means of intellectual property rights, such as patents. By taking out a patent, however, a firm also conveys information about the functioning of the invention to competitors. In this empirical paper, we highlight the trade-off of patenting by setting up a recursive system of equations on knowledge leakage and imitation that, among other factors, may be partly determined by firms' patenting activity. Thereby we contribute to the debate on the functioning of the contemporary patent system. We find that patenting firms are being less confronted with imitation. The effect of patents on the dissemination of $R \& D$ findings is, however, insignificant. Therefore, we conclude that patent disclosures do not significantly harm the appropriability conditions for inventions, but help to protect, at least partly, against imitation, as it has been originally envisaged by policy.
\end{abstract}

Keywords: Innovation, R\&D, Imitation, Dissemination, Patents

JEL Classification: O31, O33, O34, O38

Contact:

Dirk Czarnitzki

KU Leuven

Department of Management, Strategy and Innovation

Naamsestraat 69

3000 Leuven, Belgium

e-mail: dirk.czarnitzki@kuleuven.be
Kristof Van Criekingen

Aarhus University

Department of Political Science,

Danish Centre for Studies in Research and Research Policy

Bartholins Allé 7, building 1331

8000 Aarhus C, Denmark

e-mail: kvc@ps.au.dk

* Czarnitzki acknowledges financial support from the Research Foundation Flanders (grant: G0C5921N). 


\section{Introduction}

From a firm perspective two competing forces are driving the decision to invest in innovation. On the one hand, innovative performance is an important driver of firm performance and this can encourages firms to invest. On the other hand, investments in innovation suffer from negative externalities or spillovers to other firms (e.g. Arrow, 1962). Knowledge leakage in form of unintended spillover effects may induce imitation. This in turn reduces the incentives to invest. Governments have put patent systems and other policies in place to effectively counter this disincentive to invest by granting innovators a temporary monopoly to their inventions. At the same time, the patent system promotes the dissemination of useful knowledge by requiring the patentee to disclose the invention" in a manner sufficiently clear and complete for it to be carried out by a person skilled in the art" (EPC, 2013: art. 83). ${ }^{1}$ Patents may thus not only protect against imitation but possibly also accelerate technological progress by providing detailed information about inventions. Such information might not only be used for imitation (which in its narrow sense is ruled out because of the patent protection), but for superior follow-on inventions that make the patented first generation invention possibly obsolete before the legally granted patent monopoly rights expire.

The trade-off between incentives to invest in inventive activity and innovation because of positive expected returns, and disincentives because of negative externalities reducing the expected profits are the main topic of this paper. In particular, we are interested in the role of the patent system in this trade-off. On the one hand, patents should prevent imitation, but on

\footnotetext{
${ }^{1}$ The dual function of patents, facilitating appropriability of innovations and disclosing the characteristics of the invention, can also enable innovators to better negotiate licensing deals with, for example, follow on innovators (e.g. Gans et al., 2008; Arora et. al., 2001; de Rassenfosse, 2016).
} 
the other hand, they may even increase knowledge leakage as the inventor has to disclose the discovery for obtaining a patent.

To date, empirical work on imitation is scarce and largely descriptive in nature (Mansfield, 1981, 1985; Mansfield et al. 1961 Levin et al., 1985). Mansfield (1961) showed that imitation tends to follow faster when the profitability of the invention is high. Mansfield et al. (1981) ascertain that in their sample of 48 product innovations from major Northeastern US firms in the chemical, drug, electronics, and machinery industries about 60 percent of the innovations that were patented were imitated within four years. However, they also state that approximately half of the firms they studied would not have introduced their invention when it could not be patented. Mansfield (1985) showed that for a random sample of 100 highly R\&D active US firms in the thirteen major manufacturing industries in more than half the cases information regarding major $\mathrm{R} \& \mathrm{D}$ decisions leaks to the competition in less than 18 months. The information regarding the operation of a novelty leaks out in about a year after the product has been developed. Given this fast information leakage it is of no surprise that subsequent, swift imitation might occur frequently. An ill-defined patent system may thus even result in negative welfare effects (Boldrine \& Levine, 2013), as patents convey information about the underlying invention.

In this paper, we aim to follow up on the seminal contributions of Mansfield and others by relating the occurrence of knowledge dissemination and the event of imitation to firms' patenting intensity while controlling for other relevant firm level characteristics. The patent system's overall effect on innovation depends on both the strength of property rights it allocates to prevent imitation (the 'appropriation function') and the useful knowledge it helps to disseminate (the 'dissemination function') (see e.g. Fromer, 2009). The present paper empirically addresses the question of whether patents' dual functions function as envisaged. 
We use Belgian survey data on the R\&D activities of small and medium-sized firms (SMEs). Amongst other things, the survey inquired the companies about whether R\&D decisions leaked to competitors and whether the innovations resulting from their R\&D were subsequently imitated. This information allows an empirical test of our main research question: Are patents effective means to preempt imitation while facilitating the dissemination of useful knowledge?

Taking out patents does seem to have the desired effect of decreasing the probability of being imitated. This may be interpreted as a signal that the patent system is functional in terms of the enforceability of intellectual property rights (IPRs). We find the effect of taking out patents on information leakage to be insignificant. However, imitation is partly determined by information leakage.

The remainder of this paper is structured as follows: in Section 2 hypotheses are developed based on extant literature. Next, in section 3, the methodology used in the empirical study is discussed. A description of the data and variables is given and the estimation method is briefly explained. Sections 4 and 5 summarize the results from the regression analyses which are subsequently discussed in the concluding Section 6.

\section{Related literature and hypotheses}

Even though the patent system has undergone major changes over time, its effectiveness is often questioned (see e.g. Boldrin and Levine, 2013). Stiglitz (2008), for example, argues that IPRs are not the most efficient way to induce innovation in firms and sometimes can even hinder technological progress. He explains that while researchers and academics work hard to get their ideas disseminated, by contrast IPRs are designed to restrict the use of knowledge in one way or another. Therefore, a poorly designed IPR regime that creates excessively strong intellectual property rights may eventually impede innovation. The fact that many of the most 
important intellectual advances are not covered by patents (e.g. the Turing machine and ideas like asymmetric information) is indicative of other, more efficient ways to finance and produce research. When the research goal is clearly defined a prize system may be an alternative way to create incentives, using competitive markets to widely disseminate the innovation. Otherwise, government funded research and grants are good instruments to produce innovation. The main drawback being that government is picking who undertakes the research, which is not necessarily who has the best prospects of succeeding.

Patent notice, the notification of the public of the existence of a patent by adding the words "patented" or "U.S. Patent No", seems often to be failing (Bessen and Meurer, 2008) because boundaries to IP are often fuzzy. Inventers might deliberately choose to obfuscate the notice information because of incomplete appropriation of the benefits that stem from disclosure (Menell and Meurer, 2013). In a worst-case scenario, this could lead to technology gridlock (Heller, 2008) - a situation in which follow-on innovation does not occur because subsequent inventions need to draw on fragmented and uncertain IP. Licensing deals might be hindered by uncertainty surrounding the scope and extent of IPRs (Gans et al. 2008). Moreover, when the upstream technology base is fragmented, the "royalty stack" might make it unprofitable for the downstream firm to conduct the R\&D (Lemley and Shapiro, 2007).

Public policy analysis of optimal patent regimes is often framed as a trade-off between static and dynamic efficiency (Ordover, 1991). Patents, from this perspective, perform two main functions in trying to maximize these efficiencies. They, on one hand, protect firms' innovations from imitation, granting them a temporary monopoly to increase the incentives to invest in innovation (the 'appropriation' function) and, on the other hand, disseminate useful knowledge to facilitate follow-on invention (the 'dissemination' function).

In this paper we address the question of whether these two functions work as they were originally envisaged to work by policy. Theoretical modelling work on patents and imitation 
includes Horstmann et al. (1985), Anton and Yao (2004), Bhattacharya and Guriev (2006). Horstmann et al. (1985) predict that neither all inventions are patented nor all patented inventions are free from imitation. Anton \& Yao (2004) find, amongst other things, that the occurrence of imitation is contingent on the size of the inventive step. Bhattacharya and Guriev (2006) conclude from their model that an open or patented sale provides legal support for exclusion but also involves leakage of a certain portion of the knowledge in the process of filing a patent. The empirical question of whether patents impact the frequency and speed of dissemination and imitation as envisaged is an interesting question that, however, remains under-researched. To frame our hypotheses, we draw upon several branches of literature. First, regarding the 'appropriation function', we look at patents as an obstacle to imitation (see H1 below). Second, regarding the 'dissemination function', patent law provides a clear indication of how patents can serve as enablers of knowledge disclosure (see H2 below). Third, we connect both functions by considering knowledge disclosure as a driver of imitation (see $\mathrm{H} 3$ below).

\subsection{The 'appropriation' function of patents}

Governments around the world invoked a patent system to alleviate a concern expressed by Mansfield et al. (1981: 907): "If firms can imitate an innovation at a cost substantially below the cost to the innovator of developing the innovation, there may be little incentives for the innovator to carry out the innovation." Mansfield et al. (1981) acknowledge the functioning of this system as they find that half of the firms they studied would not have introduced their invention if it could not be patented. However, it often happens that potential imitators engage in $R \& D$ themselves to find a way to invent-around a patent, for example by making a similar product offering through another technique.

For patents to be valuable to innovators and enable them to recoup their $R \& D$ investments they should grant them a temporary right to exclude others from the production or 
use of the invention. In other words, patents should inhibit imitation of the patented invention by competitors. Heger and Zaby (2018) also find that having broader patents effectively deters market entry by invent-around imitators. Companies that are protect their inventions by for example taking out multiple patents on closely related inventions are mimicking this type of broader patent protection to fence off competition (see e.g. Ziedonis 2004), therefore we hypothesize :

H1: Firms that protect their knowledge through the patent system, as measured by the company patent stock, are less confronted with imitation.

\subsection{The 'dissemination' function of patents}

Patent citations are commonly used as proxies for knowledge spillovers, assuming patents serve as disclosure mechanisms (e.g. as in Jaffe et al., 1993). However, few studies have gauged the impact of patents on dissemination more directly. By construction, firms that apply for a patent make information about the nature of their R\&D investments public. The $15^{\text {th }}$ edition of the European Patent Convention (EPC, 2013) states that "The European patent application shall disclose the invention in a manner sufficiently clear and complete for it to be carried out by a person skilled in the art." (art 83). From the viewpoint of cumulative innovation, patents constitute an important mechanism by which firms can learn from their precursor innovators. Many patents are granted quite early in the innovation process, with a lot of follow on work needing to be done before the discovery is ready for an actual industrial application and introduction to the market (Mazzoleni and Nelson, 1998: 277-278). Patents could thus potentially enhance the dissemination of technological knowledge, including information regarding $R \& D$ investments. 
H2: Firms with a larger patent application stock are significantly more likely to leak important $R \& D$ investment decisions to rivals.

Since decades, however, economists have suggested that the patent dissemination function might be flawed. Bessen (2005) developed a model to assess whether the disclosure requirement of the patent system encourages the diffusion of inventions. He studied a situation in which firms choose between patents and trade secrecy to protect inventions and concluded that "diffusion of the technical information embodied in inventions is not enhanced by the patent system and may well be delayed" (Bessen, 2005: p. 127). He attributed this result mainly to the fact that firms use patents to reduce or eliminate imitation. This result also holds in a scenario where licensing is available. In a scenario with licensing, Bessen argues that licenses are given when there is a credible threat of imitation. Therefore, because patent rights limit the opportunities for imitation, the extent to which licenses are used in a no-patent regime could well be higher than when patents were available. Machlup and Pensrose (1950, p. 27) state "only unconcealable inventions are patented; concealable inventions remain concealed." The claimed disclosure function of patents is as such based on an "apples to oranges comparison". Moreover, survey evidence suggests that not much value is placed on the information disclosed in patents (Macdonald, 1998; Tang et al., 2001; Cohen et al., 2002). Patents are instead used for reasons such as keeping track of competitors or checking for infringement (Oppenheim, 1998). Since inventors might deliberately be hiding, obfuscating, and distorting notice information (Menell and Meurer, 2013), mapping the technology neighborhood might be hard and disclosure could be impeded. Furthermore, Lamoreaux and Sokoloff (1999) find empirical support for a shift towards internalizing the R\&D process within the firm, effectively limiting the role of patents as signals for prospective buyers to make an informed decision. In line with 
the above, we might expect no significant effect of the patent stock on diffusion of technological information (regarding R\&D investment decisions).

\subsection{Knowledge disclosure as a driver of imitation}

Given that information about investment decisions may leak out fast and competitors can often invent around patents, it is easy to see that imitation might occur rapidly (Mansfield, 1985). Imitation can thus occur as a staged process. Imitation has an obvious origin in products that are on the market, because these can be "re-engineered". If knowledge about the field of research and development in which a future innovator invests, or even the nature of these investments leaks to competitors, they might start their imitative R\&D effort long before the original investor's product reaches the market. Also, the potential imitators might anticipate by building up relevant absorptive capacity. Increased R\&D investment builds the absorptive capacity of a company to profit from incoming spillovers (Cohen and Levinthal, 1989). This in turn might lead to higher success rates of eventual imitation. Anton and Yao (2004) in their theoretical model assume explicitly that knowledge revealed through patent disclosures eases the imitation effort. In line with the above, we hypothesize:

H3: Leakage of a company's $R \& D$ investment decisions positively impacts the probability that their products and processes get imitated.

An overview of the hypotheses' framework can be found in Figure 1. We explain our econometric approach and the equations to be estimated in the following section in detail. 
Figure 1: Overview on research hypotheses

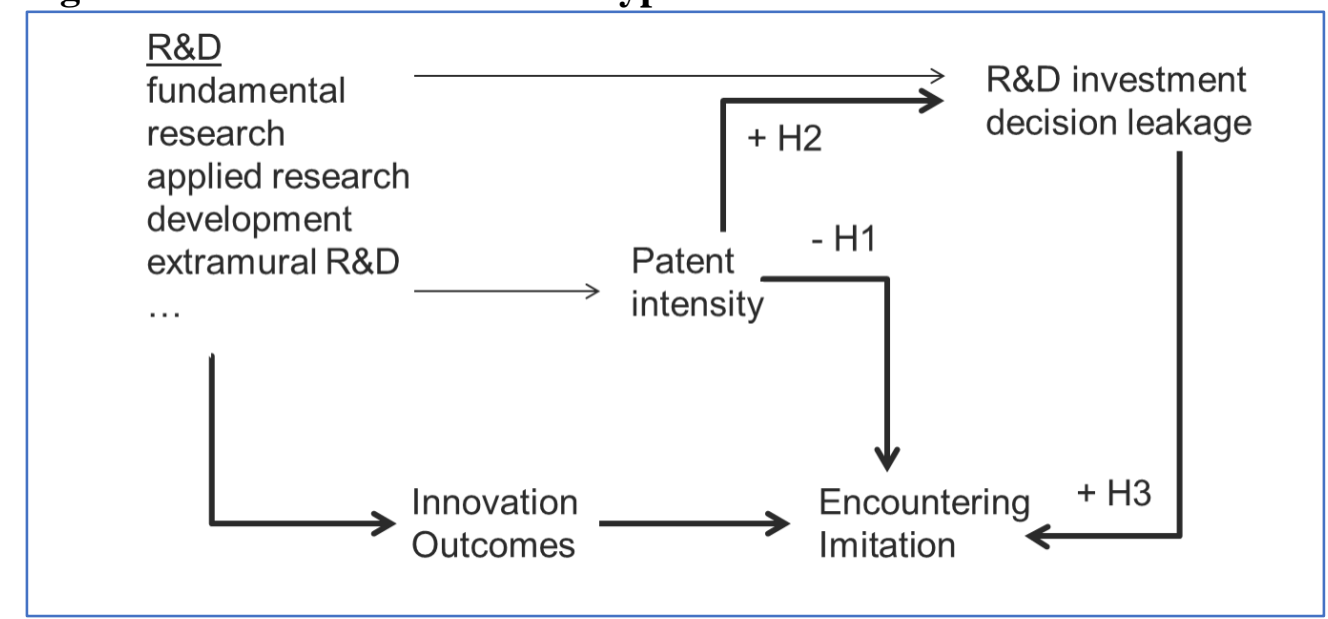

\section{Methodology and data}

\subsection{Econometric methods}

Our empirical model consists of two equations:

$$
\begin{gathered}
\text { leakage }_{i}{ }^{*}=\alpha_{1} \text { patent intensity }_{i}+X_{i}^{\prime} \beta_{1}+Z_{i}^{\prime} \gamma+\varepsilon_{1 i} \\
\text { imitation }_{i}^{*}=\alpha_{2} \text { patent intensity }_{i}+X_{i}^{\prime} \beta_{2}+\delta \text { leakage }_{i}^{*}+\varepsilon_{2 i}
\end{gathered}
$$

with $i=1, \ldots, N$, and where we observe leakage $=1$ if leakage $*>0$, and 0 otherwise as well

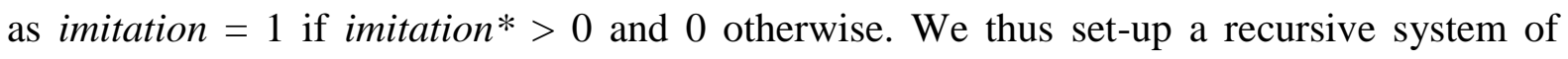
equations, where knowledge leakage is a function of patent disclosure measured by the firm's patent intensity and other variables. Imitation depends on patent protection measured through patent intensity and possible knowledge leakage and also other control variables. We expect patent intensity to have a positive coefficient $\alpha_{1}$ and a negative coefficient $\alpha_{2}$ if the patent system works as it is intended by public policy. We include a number of control variables, $X$ and instruments $Z$, which are described below in the data section. If we assume that $\operatorname{COV}\left(\varepsilon_{1}\right.$, $\left.\varepsilon_{2}\right)=0$ we can estimate the equations independently. We employ both Probit models which assume that the error terms $\varepsilon_{1}$ and $\varepsilon_{2}$ are normally distributed, and linear probability models (LPM) where we do not have to make the normality assumption. The main drawback of the LPM is that by construction the marginal effects of the regressors are constant across the range 
of the distribution. For the estimation of the Probit model, we need to make the distributional assumption of normality.

In the case that $\operatorname{COV}\left(\varepsilon_{1}, \varepsilon_{2}\right) \neq 0$, we need to account for the correlation of leakage with the error term in the imitation equation. This is done in three ways: (1) an IV regression of the LPM implemented as 2SLS, (2) a Probit IV regression (cf. Amemiya, 1978, Newey, 1987) and (3) an estimation of a bivariate Probit model which inherently accounts for the error term correlation. The latter procedure has been suggested by Greene (1998). Strictly speaking, the IV Probit regression may not be consistent in cases where the potentially endogenous regressor is not a continuous variable but a binary one. The method of Greene is exactly made for the case where the two endogenous variables are binary. It requires exclusion restrictions in the first stage which is the leakage equation in our case. In practice, the exclusion restrictions basically conform to instrumental variables and we thus use the same set of variables in all three econometric models that allow $\operatorname{COV}\left(\varepsilon_{1}, \varepsilon_{2}\right) \neq 0$.

\subsection{Data sources and variables}

The database used to conduct the analysis originates from the Flemish part of the Eurostat/OECD R\&D Survey, an inquiry about the R\&D activity in the Flemish economy carried out bi-annually. The R\&D methodological standards comprise a stratified random sampling procedure and a comprehensive non-response analysis to ensure representativeness of the sample for the Flemish economy as a whole. The data consists of one cross-section of the Flemish economy surveyed in 2014 about their activities in the period spanning 2012-2013. We use the survey carried out in 2014 since it includes unique questions on diffusion of R\&D projects and their corresponding investments and eventual imitation of products and processes. These survey questions are closely related to the seminal work by Mansfield (1985). Companies were asked whether they were confronted with leakage of important $R \& D$ 
investment decisions and imitation. Additionally, they were inquired about the time it took for these events to occur.

These 'Mansfield' questions were pre-tested in some detailed face-to-face interviews about the firms' understanding of the survey instrument. While this is common practice within the R\&D survey, we paid special attention to these additional question as they are usually not included. It turned out that the questions on the incidence of knowledge leakage and imitation were well understood by the respondents and they found them easy to answer. The question on the dissemination speed, however, as it was included in Mansfield's original work back in 1985 was found to be difficult, even when we asked for a rough estimate of elapsed time. Therefore, we mainly base our subsequent analysis mainly on the events of leakage and imitation irrespective of the timing.

In addition to the survey data, we collected patent data for all surveyed firms from the Patstat database which will be used to calculate patent stocks. All, worldwide, patent applications were retrieved from Patstat based on name and address matching of the applicants. The patent applications are aggregated at the family level to obtain unique inventions rather than a document count.

The sample covers firms in the manufacturing as well as the business service sector. We restrict the sample to $R \& D$ performing firms as the interest lies in imitation of product and process innovations which required upfront $R \& D$ investments. Considering item non-response on some of the variables used in our specifications of regression equations, the final estimation sample counts 423 observations. ${ }^{2}$ This sample amounts to about $10 \%$ of the population of the Flemish R\&D performers.

\footnotetext{
${ }^{2}$ As expected, however, only about 100 companies reported estimations of investment decision leakage speed and imitation speed.
} 


\subsection{Dependent variables}

LEAKAGE indicates if a company's important $\mathrm{R} \& \mathrm{D}$ decisions leaked to competitors. In the sample, $65 \%$ of companies reported that important information about their R\&D projects leaked to competitors (see Table 2).

As mentioned above, in his seminal work, Mansfield tabulated the speed of diffusion as result of information leakage as reported by top US R\&D performers. Mansfield found that it took about 12 to 18 months in the early 1980s until information about a companies' important R\&D projects spilled over to rivals. As we reported above, our data on the elapsed time suffers from high non-response and we refrain from using that in a more detailed econometric study. However, it seemed noteworthy to briefly report some descriptive results. Intuitively, one might expect that the rise of information and communication technology and digitalization in general have even accelerated the diffusion process. However, our findings contradict this. The numbers obtained from our survey are well in line with the findings of Mansfield some decades ago. On average, the respondents reported that it takes about 15 months until important information has leaked to competitors. $32 \%$ of firms report that it took 6 to 12 months, $28 \%$ report 12 to 18 months, and $30 \%$ even mention 18 months or more (see Table 1 ).

The variable IMITATION indicates whether a company's products or processes were imitated in the past 10 years. $46 \%$ of companies report that imitation of their products eventually happened. With respect to the speed of imitation, we find consistent results with the knowledge leakage question. On average, imitation happens after 19 months the product has been introduced to the market. The majority of companies (67\%), however, reports that it takes less than 18 months after product market introduction until imitation takes place $(11 \%+14 \%+31 \%)($ see Table 1$)$. 
Table 1: Speed of knowledge leakage and imitation

\begin{tabular}{|lcccc|}
\hline & \multicolumn{2}{c}{$\begin{array}{c}\text { Speed of diffusion } \\
\text { (knowledge leakage) } \\
\text { Number of } \\
\text { observations }\end{array}$} & Rel. Freq. & \multicolumn{2}{c|}{$\begin{array}{c}\text { Speed of imitation } \\
\text { Number of } \\
\text { observations }\end{array}$} & Rel. Freq. \\
\hline Less than 6 months & 8 & $10 \%$ & 11 & $11 \%$ \\
6 to 12 months & 26 & $32 \%$ & 14 & $14 \%$ \\
12 to 18 months & 23 & $28 \%$ & 30 & $31 \%$ \\
18 months and more & 25 & $30 \%$ & 42 & $43 \%$ \\
\hline Total & 82 & $100 \%$ & 97 & $100 \%$ \\
\hline Mean & 14.9 & & 19.0 & \\
\hline
\end{tabular}

\subsection{Explanatory variables}

Our main variable of interest is the patent stock (PS) for firm $i$ in year $t$, which is calculated by the commonly used perpetual inventory method as

$$
P S_{i t}=(1-\delta) P S_{i t-1}+\text { patent applications } s_{i t}
$$

where $\delta$, the rate of obsolescence, is set to $15 \%$ as is standard in the literature (e.g. Griliches and Mairesse, 1984; Hall, 1990; Czarnitzki and Kraft, 2010). The patent data include all patents from 1980 to 2013 (the survey reference year), and we therefore obtain a comprehensive picture of firms' patent portfolios. Note again that we aggregate the data to the patent family level, i.e. we count patented inventions and not patent documents.

In the regressions, we use the variable PATENT INTENSITY $=$ PS/employment to avoid collinearity with firm size. We expect patent intensity to have a positive sign in the knowledge leakage equation and a negative sign in the imitation equation if the patent system works as anticipated by public policy.

Apart from the patenting behavior there are several firm level characteristics that can influence the chances a firm gets confronted with imitation and knowledge leakage. Since these other drivers of imitation are potentially correlated with the patenting strategy of a firm it is important to control for them in our analyses as otherwise they might constitute an omitted variable bias. 
While ample studies investigate the link between firm growth and innovation (e.g. Coad and Rao, 2008; Goedhuys and Veugelers, 2012; Audretsch et al. 2014), not much has been said about how and why firms are being confronted with imitation. Also, the broad literature on spillovers and growth remains largely silent about possibly induced imitation. Hereunder we consider firms' industry characteristics, $R \& D$, and export profile as drivers of imitation and knowledge dissemination.

$\mathrm{R} \& \mathrm{D}$ is the most important input in creating new products and processes. Given the high-risk profile of $R \& D$ investments companies that make these investments assume that in the end their efforts will result in higher mark-ups (e.g. Cohen and Klepper, 1996). Since R\&D produces mainly knowledge, which is a public good, these investments might suffer from negative externalities or spillovers. This makes it a relevant control variable. The more R\&D a firm conducts the more likely it is that some information about investment projects leaks to competitors. Furthermore it can be expected that R\&D-intensive companies have a range of product on the market and therefore also imitation might occur with a higher likelihood. We include two measures of $R \& D$, internal and external $R \& D$. The risk of leakage and imitation might even be higher when companies also pursue external $R \& D$, as they most likely have to disclose some parts of their internal project to complement their in-house activity with the external contracts successfully. Again we use R\&D per employee in the regression to avoid multicollinearity with firm size. We this include INTERNAL R\&D INTENSITY and EXTERNAL R\&D INTENSITY in the regressions (in thousand Euros per employee).

Companies may conduct three types of R\&D activity: strategic-basic research, applied research and development. For manufacturing industries it has been shown that strategic-basic research has a productivity impact. Mansfield (1980) shows that the impact of basic research on total factor productivity is not only positive but also larger than the same expenditure on applied R\&D (see also Diamond, 2003; Czarnitzki and Thorwarth, 2012). Moreover, 
investments in basic research can provide companies with a longer lasting technological advantage over competitors since the results from this type of research are not as directly applicable as output from applied research and development investments. Since more prerequisite knowledge is required to interpret and further apply basic research results, this type of investment might be less prone to relevant knowledge leakage to competitor and also less likely to lead to imitation. In contract, applied research and development may have a direct consequence of rivals in the same technological domain and may therefore be associated with higher leakage and imitation rates than basic research. Consequently we include the variables APPLIED R\&D and DEVELOPMENT as percentages in total R\&D. Thereby, the share of strategic-basic research serves as reference category (the sum of the shares of three types sums up to the unit vector).

Exporting can make firms benefit from a larger market to sell their products and it also provides the occasion to scout for new inventions in foreign markets (Barrios et al., 2003). The idea of learning-by-exporting is a highly discussed topic by economists. Salomon and Jin (2010) mention that exporting firms that lack a decent technology or know-how may benefit the most from this kind of learning as foreign markets put technologies at their disposal which they can adapt to improve their business operations. However, diffusion of existing technologies tends to happen faster when firms are clustered in the same area (Pederson, 1970). This is especially true for high-tech industries (Audretsch and Feldman, 1996). Exporting firms have their products present on a larger set of geographical markets. They might also decide to have a local base of operations on the export market. Thus, while exporting might provide firms with the opportunity of learning-by-exporting, when a firm has a technology that is better than that of the export market it might suffer from both knowledge leakage and imitation due to exporting. The variable EXPORT measures the percentage of sales that was not generated domestically (within Belgium). 
Further, general controls on firm size, measured by EMPLOYMENT, and AGE are included in the regressions in logarithmic form. We also control for sectors. Based on NACE2codes, we construct a set of sector dummies. Firms in industries that are reliant on technologies based on heavily codified knowledge might be more likely to suffer from knowledge leakage and imitation (Teece, 1986). Descriptive statistics of all variables can be found in Table 2, and the sector aggregation used to make the sector dummies is shown in the appendix in Table 6 . The appendix also contains a bivariate correlation table.

\subsection{Instrumental Variables}

We instrument the $L E A K A G E$ variable to account for possible endogeneity in regressions on imitation. Given that we conjecture that knowledge diffusion,. i.e. information leakage, influences imitation in a staged process and potential unobserved important drivers of imitation could correlate with knowledge diffusion, we explore an instrumental variable approach. Finding fully convincing instruments is always challenging in settings where no natural experiment can be utilized. As we use cross-sectional survey data, our options where limited. Our search for candidates yielded the following two candidates as best suited given our options: we use the number of EXTERNAL ON-SITE CONSULTANTS working on the companies' internal $R \& D$ activities, and as often done in industrial economic context the sectoral frequency of the phenomenon of interest, that is, the industry average of $L E A K A G E$ at detailed NACE levels $(A V G . L E A K A G E){ }^{3}$

For the first instrumental variable we make use of a recently introduced feature to the OECD guidelines on how to collect R\&D data (OECD 2015). The survey respondents were supposed to include consultants that work on-site of the firms' premises in their intramural

\footnotetext{
${ }^{3}$ The sectoral leakage variable is measures at a much finer industry level than the 11 sectors that are used as dummies in the subsequent regression analysis. We used the 3-digit NACE level as starting point. In case there were only a few firms in a 3-digit sector we merged related sectors in order to obtain reliable numbers of observations for aggregating leakage as the industry level.
} 
R\&D expenses, and the information on the number of external consultants involved in a firm's R\&D has been collected in a separate question. External R\&D consultants get to know R\&D projects a company is conducting early on, and they may diffuse possible knowledge gained among their other clients. We thus use the number of external on-site consultants as an explanatory variable for $L E A K A G E$. It is reasonable they are exempt from directly imitating the firms' research and development activities and thus also products by means of, for example, non-compete clauses in their consulting contracts. We thus argue that it has no direct impact on imitation conditional on the other controls.

Furthermore, we consider the industry-level leakage as an indicator how free information flows in the sector as exogenous to the firm (cf. Czarnitzki and Kraft 2012 on knowledge spillovers). Therefore, the industry average of how free information flows in the sector, will also impact the chance that leakage happens at the focal firm. It should however not have a direct effect on the likelihood of imitation once we accounted for the other drivers of imitation at the firm level. ${ }^{4}$

The two instruments will also serve as exclusion restrictions in the recursive bivariate estimation based on Greene's (1998) approach.

\footnotetext{
${ }^{4}$ We mainly use two instruments in order to conduct a test of overidentifying restrictions which does not reject the validity of the instruments. However, we also estimated the models with each instrument separately and the results remain similar.
} 
Table 2: Descriptive Statistics (423 Observations)

\begin{tabular}{|c|c|c|c|c|c|}
\hline VARIABLE & Variable description & Mean & $\begin{array}{l}\text { Std. } \\
\text { Dev. }\end{array}$ & Min & $\operatorname{Max}$ \\
\hline $\begin{array}{l}\text { IMITATION } \\
(\text { DUMMY) }\end{array}$ & $\begin{array}{l}\text { Indicates whether a company was } \\
\text { confronted with initiation of its products } \\
\text { and processes (in the past } 10 \text { years) }\end{array}$ & 0.46 & 0.50 & 0 & 1 \\
\hline LEAKAGE (DUMMY) & $\begin{array}{l}\text { Indicates whether a company was ever } \\
\text { confronted with leakage of its R\&D } \\
\text { investment decisions }\end{array}$ & 0.65 & 0.48 & 0 & 1 \\
\hline PATENT INTENSITY & Depreciated patent stock per employee & 0.02 & 0.09 & 0 & 0.92 \\
\hline EXPORT $(\%)$ & $\begin{array}{l}\text { Percentage of turnover generated from } \\
\text { exports outside Belgium }\end{array}$ & 47.14 & 37.26 & 0 & 100 \\
\hline $\begin{array}{l}\text { FUNDAMENTAL } \\
R \& D(\%)\end{array}$ & $\begin{array}{l}\text { Percentage of intramural R\&D } \\
\text { expenditures spend on fundamental } \\
\text { research }\end{array}$ & 8.95 & 18.84 & 0 & 100 \\
\hline $\begin{array}{l}\text { APPLIED RESEARCH } \\
(\%)\end{array}$ & $\begin{array}{l}\text { Percentage of intramural R\&D } \\
\text { expenditures spend on applied research }\end{array}$ & 47.83 & 35.18 & 0 & 100 \\
\hline DEVELOPMENT (\%) & $\begin{array}{l}\text { Percentage of intramural R\&D } \\
\text { expenditures spend on development }\end{array}$ & 43.22 & 35.46 & 0 & 100 \\
\hline $\begin{array}{l}\text { INTERNAL R\&D } \\
\text { INTENSITY }\end{array}$ & $\begin{array}{l}\text { Intramural R\&D expenditures / } \\
\text { employment }\end{array}$ & 29.81 & 41.65 & 0.059 & 389 \\
\hline $\begin{array}{l}\text { EXTERNAL R\&D } \\
\text { INTENSITY }\end{array}$ & $\begin{array}{l}\text { Extramural R\&D expenditures / } \\
\text { employment }\end{array}$ & 3.08 & 13.04 & 0 & 157 \\
\hline$A G E$ & 2013- year of foundation & 20.27 & 15.21 & 0 & 88 \\
\hline EMPLOYMENT & Number of employees & 45.71 & 53.03 & 1 & 233 \\
\hline$A V G . L E A K A G E$ & $\begin{array}{l}\text { Industry average of } L E A K A G E \text { at the 3- } \\
\text { digit NACE sector level }\end{array}$ & 0.65 & 0.16 & 0 & 1 \\
\hline $\begin{array}{l}\text { EXTERNAL ON-SITE } \\
\text { CONSULTANTS }\end{array}$ & $\begin{array}{l}\text { Number of external consultants working } \\
\text { on the firm's internal R\&D }\end{array}$ & 0.89 & 2.43 & 0 & 25 \\
\hline
\end{tabular}

Note: We also include 11 sector dummies in each regression of the subsequent analysis.

\section{Econometric study}

We first estimate separate, single equation Probit model both knowledge leakage and imitation.

To consider possible endogeneity of the $L E A K A G E$ variable, we further estimate a recursive bivariate probit model (Greene, 1998; Greene, 2003) where we use the industry average of the investment decision leakage variable and the number of external on-site R\&D consultants as exclusion restrictions for the model to be identified.

In an instrumental variables Probit regression, we instrument $L E A K A G E$ with the number of external consultants and the industry average of R\&D investment decision leakage. This approach allows to inspect the validity of the instrument by means of a test of overidentifying restrictions following Lee (1992). 
Finally, we also estimate LPMs and 2SLS regressions as robustness tests.

\subsection{Single equation Probit models}

Table 3 contains the results of univariate probit estimations. The initial specification on LEAKAGE and IMITATION (cf. columns 1 and 2) only includes our main variable of interest, PATENT INTENSITY, and general firm level controls size, age and sector dummies, as well as the exclusion restrictions/instruments in the LEAKAGE equation. In columns 3 and 4, we add the other controls. It turns out the inclusion of the further controls do not change any interpretation of the results.

In line with H1, PATENT INTENSITY has a negative sign in the imitation equation and is also highly statistically significant. However, we do not find confirmation for $\mathrm{H} 2$, i.e. a higher patent intensity which indicates more disclosure of a firm's inventions does not lead to a significantly higher $L E A K A G E$ propensity. The estimated coefficient is insignificant.

We find strong evidence for H3, however. LEAKAGE leads to a higher imitation probability of the firms' new products.

The exclusion restrictions average sectoral leakage and external R\&D on-site consultants show positive signs in the leakage equation and are highly significant. We talk more about their relevance and exogeneity in the IV section below.

With regard to the control variables we largely find the expected results in the imitation equation. The more applied $R \& D$ and development (in comparison to basic research) are conducted, the more likely imitation happens. This is also the case for higher export sales, possibly due to the exposure of more markets, higher firm age and also larger firm size. Both older firms and larger firms' products are observed by more competitors or more carefully by a given number of focal competitors. We do not find statistical significance of internal and external $R \& D$, nor the sector dummies. In the leakage equation, the internal $R \& D$ intensity is 
positive and statistically significant as expected. The other variables do not explain information leakage regarding $R \& D$ projects in a statistically significant extent.

Table 3: Single Equation Probit Estimations

\begin{tabular}{|c|c|c|c|c|}
\hline $\mathrm{b} /(\mathrm{se})$ & $\begin{array}{c}(1) \\
\text { LEAKAGE }\end{array}$ & $\begin{array}{c}(2) \\
\text { IMITATION }\end{array}$ & $\begin{array}{c}(3) \\
\text { LEAKAGE }\end{array}$ & $\begin{array}{c}(4) \\
\text { IMITATION }\end{array}$ \\
\hline$L E A K A G E$ & & $\begin{array}{l}0.476 * * * \\
(0.135)\end{array}$ & & $\begin{array}{l}0.465 * * * \\
(0.138)\end{array}$ \\
\hline PATENT INTENSITY & $\begin{array}{c}-0.371 \\
(0.778)\end{array}$ & $\begin{array}{c}-3.130 * * \\
(1.583)\end{array}$ & $\begin{array}{l}-0.283 \\
(0.775)\end{array}$ & $\begin{array}{c}-3.429 * * \\
(1.659)\end{array}$ \\
\hline EXPORT (\%) & & & $\begin{array}{c}0.000 \\
(0.002)\end{array}$ & $\begin{array}{c}0.005 * * \\
(0.002)\end{array}$ \\
\hline$A P P L I E D R \& D(\%)$ & & & $\begin{array}{l}-0.003 \\
(0.004)\end{array}$ & $\begin{array}{c}0.011 * * * \\
(0.004)\end{array}$ \\
\hline DEVELOPMENT (\%) & & & $\begin{array}{c}-0.005 \\
(0.004)\end{array}$ & $\begin{array}{c}0.012 * * * \\
(0.004)\end{array}$ \\
\hline INTERNAL R\&D INTENSITY & & & $\begin{array}{l}0.004 * \\
(0.003)\end{array}$ & $\begin{array}{c}0.002 \\
(0.002)\end{array}$ \\
\hline EXTERNAL R\&D INTENSITY & & & $\begin{array}{c}0.005 \\
(0.009)\end{array}$ & $\begin{array}{l}-0.002 \\
(0.006)\end{array}$ \\
\hline $\log A G E$ & 0.020 & $0.199 * *$ & 0.063 & $0.247 * *$ \\
\hline T) & $(0.103)$ & $(0.099)$ & $(0.106)$ & $(0.103)$ \\
\hline Log EMPLOYMENT & $\begin{array}{l}-0.058 \\
(0.069)\end{array}$ & $\begin{array}{l}0.141 * * \\
(0.064)\end{array}$ & $\begin{array}{c}0.004 \\
(0.076)\end{array}$ & $\begin{array}{l}0.118^{*} \\
(0.071)\end{array}$ \\
\hline AVG. LEAKAGE & $\begin{array}{l}3.323 * * * \\
(0.514)\end{array}$ & & $\begin{array}{l}3.337 * * * \\
(0.525)\end{array}$ & \\
\hline $\begin{array}{l}\text { EXTERNAL R\&D ON-SITE } \\
\text { CONSULTANTS }\end{array}$ & $\begin{array}{c}0.176 * * * \\
(0.058)\end{array}$ & & $\begin{array}{l}0.148 * * \\
(0.059)\end{array}$ & \\
\hline Joint sig. sector dummies (p-value) & 0.999 & 0.444 & 0.999 & 0.379 \\
\hline Pseudo $\mathrm{R}^{2}$ & 0.120 & 0.088 & 0.132 & 0.122 \\
\hline Number of observations & 423 & 423 & 423 & 423 \\
\hline Wald test on model significance & $65.786 * * *$ & $51.536 * * *$ & $72.472 * * *$ & $71.127 * * *$ \\
\hline
\end{tabular}

Notes: All regressions include an intercept. Significance levels: *** 1 pct. or less; ** less than 5 pct. , * less than 10 pct.

\subsection{Bivariate Probit and IV Probit}

Table 4 reports the results from a recursive bivariate Probit estimation of the system of equations according to Greene (1998) and an IV Probit regression. Both models lead to very similar results. As the first stage of the model on $L E A K A G E$ is basically the same as in the single-equation Probit model, we refrain from discussing the results in more detail again. In the model's second stage on imitation, we find comparable results to the single equation models: $L E A K A G E$ is positive and significant. The patent intensity is statistically significant and reduces the likelihood of imitation. 
We also conducted a test overidentifying restrictions following Lee (1992) and it does not reject the validity of the instruments (average leakage at industry level and number of external on-site R\&D consultants).

Table 4: Bivariate Probit and IV Probit

\begin{tabular}{|c|c|c|c|}
\hline & Bivari & obit & $\begin{array}{c}\text { IV probit } \\
\left(2^{\text {nd }} \text { stage; see Table } 3 \text {, col. }\right. \\
\left.3, \text { for } 1^{\text {st }} \text { stage }\right)\end{array}$ \\
\hline $\mathrm{b} /(\mathrm{se})$ & LEAKAGE & IMITATION & IMITATION \\
\hline$L E A K A G E$ & & $\begin{array}{c}0.763 * * * \\
(0.356)\end{array}$ & $\begin{array}{c}0.882 * * * \\
(0.415)\end{array}$ \\
\hline PATENT INTENSITY & $\begin{array}{l}-0.279 \\
(0.775)\end{array}$ & $\begin{array}{c}-3.398 * * \\
(1.638)\end{array}$ & $\begin{array}{c}-3.460 * * \\
(1.661)\end{array}$ \\
\hline EXPORT (\%) & $\begin{array}{c}0.000 \\
(0.002)\end{array}$ & $\begin{array}{c}0.005 * * \\
(0.002)\end{array}$ & $\begin{array}{c}0.005 * * \\
(0.002)\end{array}$ \\
\hline APPLIED RESEARCH (\%) & $\begin{array}{l}-0.003 \\
(0.004)\end{array}$ & $\begin{array}{c}0.011 * * * \\
(0.004)\end{array}$ & $\begin{array}{c}0.011 * * * \\
(0.004)\end{array}$ \\
\hline DEVELOPMENT (\%) & $\begin{array}{l}-0.005 \\
(0.004)\end{array}$ & $\begin{array}{c}0.012 * * * \\
(0.004)\end{array}$ & $\begin{array}{c}0.013 * * * \\
(0.004)\end{array}$ \\
\hline$R \& D$ INTENSITY & $\begin{array}{l}0.004^{*} \\
(0.003)\end{array}$ & $\begin{array}{c}0.002 \\
(0.002)\end{array}$ & $\begin{array}{c}0.002 \\
(0.002)\end{array}$ \\
\hline EXTERNAL R\&D & $\begin{array}{c}0.004 \\
(0.009)\end{array}$ & $\begin{array}{l}-0.002 \\
(0.006)\end{array}$ & $\begin{array}{l}-0.002 \\
(0.006)\end{array}$ \\
\hline $\log A G E$ & $\begin{array}{c}0.061 \\
(0.106)\end{array}$ & $\begin{array}{r}0.235^{* *} \\
(0.104)\end{array}$ & $\begin{array}{r}0.235^{* *} \\
(0.105)\end{array}$ \\
\hline Log EMPLOYMENT & $\begin{array}{c}0.002 \\
(0.076)\end{array}$ & $\begin{array}{c}0.111 \\
(0.071)\end{array}$ & $\begin{array}{c}0.110 \\
(0.072)\end{array}$ \\
\hline$A V G . L E A K A G E$ & $\begin{array}{r}3.306 * * \\
(0.513)\end{array}$ & & \\
\hline $\begin{array}{l}\text { EXTERNAL R\&D ON-SITE } \\
\text { CONSULTANTS }\end{array}$ & $\begin{array}{c}0.155^{* * * *} \\
(0.061)\end{array}$ & & \\
\hline Number of observations & \multirow{2}{*}{\multicolumn{2}{|c|}{$\begin{array}{c}423 \\
118.607 * * *\end{array}$}} & 423 \\
\hline Wald test on model significance & & & $53.44 * * *$ \\
\hline $\begin{array}{l}\text { Joint Sig. sector dummies } \\
\text { (p-value) } \\
\text { RHO }\end{array}$ & 0.9987 & 0.4081 & 0.4113 \\
\hline
\end{tabular}

Notes: All regressions include an intercept.

Significance levels: *** 1 pct. or less; ** less than 5 pct. , * less than 10 pct.

A test of over identifying restrictions following Lee (1992) does not reject the validity of the instruments $A V G$. LEAKAGE and EXTERNAL R\&D CONSULTANTS).

In the bivariate Probit following Greene (1998), the RHO parameter is negative but insignificant. 
The magnitude of the negative patent intensity effect on imitation can be shown best by looking at the change in the predicted probabilities (instead of just calculating average marginal effects). The predicted probabilities of different patent intensity values in the sample are shown in Figure 2. We also calculate the marginal effect as a discrete jump for some selected values. For instance, changing the patent intensity from 0 to the mean (of the strictly positive values) decreases the predicted probability of being imitated by little over 10 percentage points. Going from the mean of patent intensity to the $95^{\text {th }}$ percentile decreases the predicted probability by about 31 percentage points.

Figure 2: Predicted probabilities of imitation conditional on patent intensity

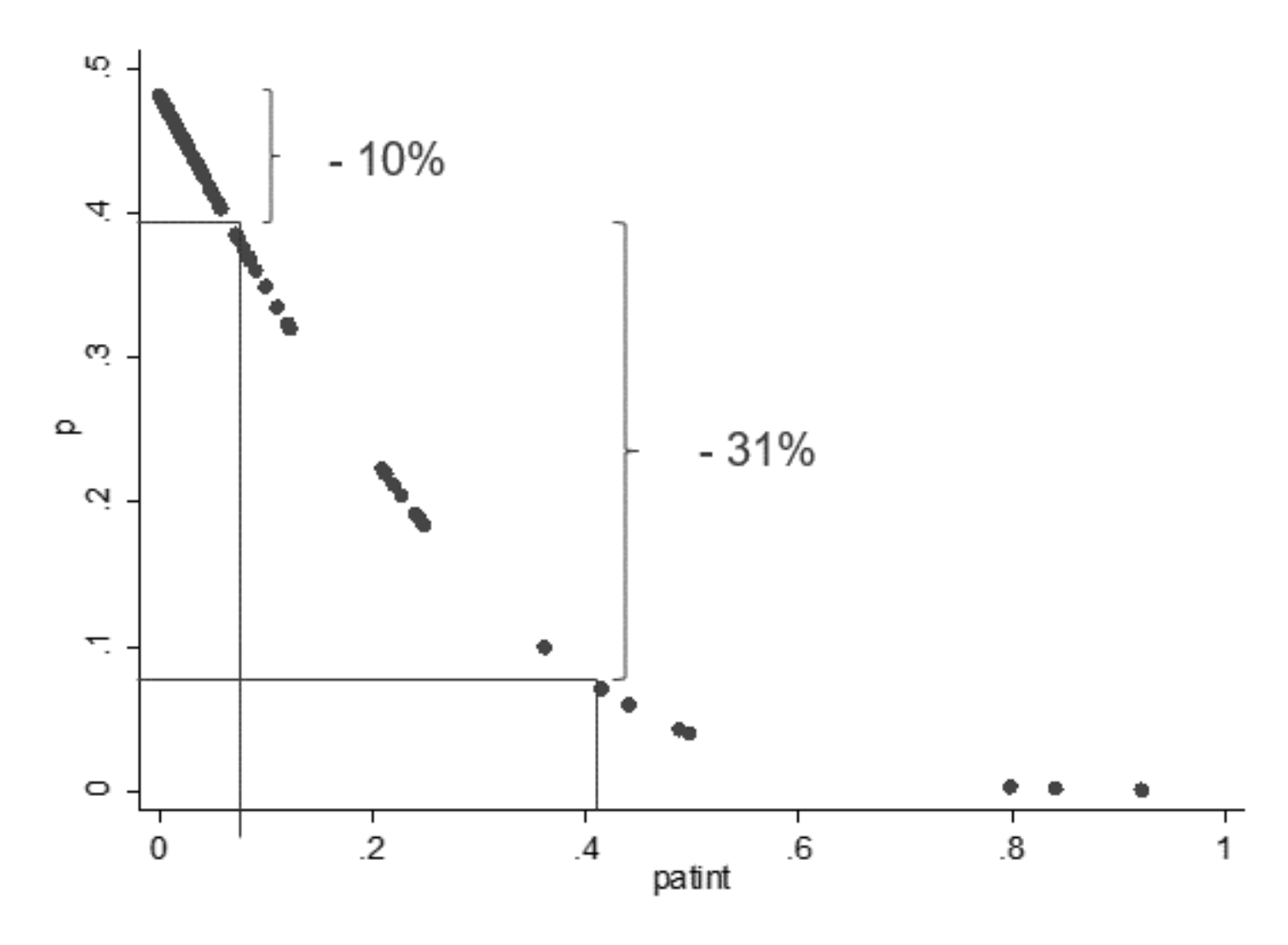

A switch of the $L E A K A G E$ variable from zero to one increases the predicted probability of imitation by about 17 percentage points, meaning that companies that leak important $R \& D$ investment decisions are 17 percentage points more likely to be hit by imitation later. 


\subsection{Linear Probability model and 2 SLS}

In this subsection we briefly present the results of linear probability models and a 2SLS IV regression. In the first two columns we present the results of LPMs, i.e. the two equations are estimated independently. In the third column we show the results for the $2^{\text {nd }}$ stage of the 2SLS regression for the imitation equation (the first stage is equivalent to the results shown for LEAKAGE in the first column).

Table 5: Linear Probability models and 2SLS

\begin{tabular}{|c|c|c|c|}
\hline & \multicolumn{2}{|c|}{ LPM } & 2 SLS (2 $2^{\text {nd }}$ stage $)$ \\
\hline $\mathrm{b} /(\mathrm{se})$ & $\begin{array}{l}\text { LEAKAGE } \\
\left(1^{\text {st }} \text { of } 2 \text { SLS }\right)\end{array}$ & IMITATION & IMITATION \\
\hline $\begin{array}{l}\text { LEAKAGE } \\
\text { PATENT INTENSITY }\end{array}$ & $\begin{array}{l}-0.119 \\
(0.248)\end{array}$ & $\begin{array}{c}0.161 * * * \\
(0.049) \\
-0.574 * * * \\
(0.143)\end{array}$ & $\begin{array}{c}0.314 * * * \\
(0.134) \\
-0.588 * * * \\
(0.161)\end{array}$ \\
\hline EXPORT (\%) & $\begin{array}{l}0.0001 \\
(0.001)\end{array}$ & $\begin{array}{c}0.002 * * * \\
(0.001)\end{array}$ & $\begin{array}{l}0.002 * * \\
(0.001)\end{array}$ \\
\hline APPLIED RESEARCH (\%) & $\begin{array}{l}-0.001 \\
(0.001)\end{array}$ & $\begin{array}{c}0.003 * * * \\
(0.001)\end{array}$ & $\begin{array}{c}0.004 * * * \\
(0.001)\end{array}$ \\
\hline DEVELOPMENT (\%) & $\begin{array}{l}-0.001 \\
(0.001)\end{array}$ & $\begin{array}{c}0.004 * * * \\
(0.001)\end{array}$ & $\begin{array}{c}0.004 * * * \\
(0.001)\end{array}$ \\
\hline$R \& D$ INTENSITY & $\begin{array}{l}0.0013 * \\
(0.0007)\end{array}$ & $\begin{array}{c}0.001 \\
(0.001)\end{array}$ & $\begin{array}{c}0.001 \\
(0.001)\end{array}$ \\
\hline EXTERNAL R\&D & $\begin{array}{c}0.001 \\
(0.001)\end{array}$ & $\begin{array}{l}-0.001 \\
(0.002)\end{array}$ & $\begin{array}{l}-0.001 \\
(0.002)\end{array}$ \\
\hline $\log A G E$ & $\begin{array}{c}0.014 \\
(0.003)\end{array}$ & $\begin{array}{c}0.088 * * \\
(0.034)\end{array}$ & $\begin{array}{r}0.083 * * \\
(0.034)\end{array}$ \\
\hline Log EMPLOYMENT & $\begin{array}{c}0.004 \\
(0.026) \\
\end{array}$ & $\begin{array}{l}0.045^{*} \\
(0.025) \\
\end{array}$ & $\begin{array}{l}0.042 * \\
(0.025) \\
\end{array}$ \\
\hline $\begin{array}{l}\text { AVG. LEAKAGE } \\
\text { EXTERNAL R\&D ON-SITE } \\
\text { CONSULTANTS }\end{array}$ & $\begin{array}{c}1.008 * * * \\
(0.121) \\
0.024 * * * \\
(0.007) \\
\end{array}$ & & \\
\hline Sector dummies & Incl. & Incl. & Incl. \\
\hline $\begin{array}{l}\text { Number of observations } \\
\text { F-test on model significance } \\
\text { R-squared } \\
\text { Joint significance of instruments }(A V G \text {. } \\
\text { LEAKAGE and EXTERNAL R\&D ON- } \\
\text { SITE CONSULTANTS): F-test } \\
\text { Test of overidentifying restrictions } \\
(\text { Chi^2 test) }\end{array}$ & $\begin{array}{c}423 \\
5.95 * * * \\
0.143\end{array}$ & $\begin{array}{c}423 \\
6.33 \\
0.150\end{array}$ & $\begin{array}{c}0.031 \\
\text { (p-value: } 0.86)\end{array}$ \\
\hline
\end{tabular}

Notes: All regressions include an intercept. Robust standard errors in brackets.

Significance levels: *** 1 pct. or less; ** less than 5 pct. , * less than 10 pct.

The results are comparable to the Probit models. Of course the magnitude of the coefficients differ, but the interpretation remains the same: patent intensity does not significantly trigger 
leakage but the patents prevent imitation to a certain extent. Once important information on R\&D projects have leaked, the firm faces a higher risk of imitation.

\section{Discussion and conclusion}

In this study we analyzed the disclosure function and the appropriation function of patents by adopting a survey methodology that had been originally considered by Mansfield (1985). He asked firms whether important information regarding R\&D projects leaked out of the firm, and whether the respective firms had faced imitation of their products. We relate such information to the firms' patent intensity and a number of control variables.

With regard to the appropriation function of patents, we find evidence supporting the view that patents have the desired effect of lowering the probability to get imitated. These findings are robust across a number of different econometric models including single-equation Probit and linear probability models, as well as system of equations where we account for the possible endogeneity of leakage (Bivariate Probits with endogenous regressor, IV Probit, and 2SLS). Our results are thus suggestive of patents being functional countermeasures to imitation to a certain extent.

While we control for relevant characteristics of the firms' innovation profile one might be concerned with a potential reverse causality interpretation where companies hit by imitation increase their patenting activity in reaction. We argue, this reasoning, while valid, should not form a major point of concern. In an additional robustness check (results not reported) we dropped the patents applied for in the period overlapping with the surveyed period from the patent stock. We thus use long lags of patents and still find results which are significant - the significance level often drops to the 10 percent level, however. This should not come as a surprise though, as most of the imitation happens rather fast, i.e. in less than 1.5 years. 
Our analysis also points to the fact that $\mathrm{R} \& \mathrm{D}$ investment decisions are not more likely to be leaked if a company patents its inventions more intensely. We interpret that that disclosure function of patents by the publication of the invention is thus no significant channel for the information leakage within important R\&D projects.

Given the potential deficiencies patents cause from a social welfare perspective (e.g. monopoly rents, dynamic inefficiencies in innovation) policy makers should however be aware that a well-behaved patent protection function in terms of imitation could still potentially lead to a suboptimal outcome in terms of social welfare. While our research shows that the protection function of the patent system is working in the sense that it reduces the risk of imitation by an economically meaningful magnitude we cannot conclude on total welfare effects. From a welfare perspective, it remains unclear whether imitation is desirable to a certain degree in order to compensate partly the deadweight loss induced by the patent system because of temporary monopoly positions, on the one hand. In the extreme case of the complete absence of patent protection on the other hand, it is highly questionable whether inventors would still have sufficient incentives to explore and to create patentable discoveries.

Regarding the driving factors of imitation, we find some evidence of imitation due to exporting. The analysis points out that companies with high export shares seem to be hit more by imitation. Also, companies investing more into applied research and development efforts as opposed to basic research are more prone to being imitated on the market.

Leakage of (early stage) R\&D investment decisions depends on the involvement of external R\&D on-site consultants. Although these might have had to sign non-compete and secrecy clauses in their contracts, it could still happen that they contribute to information diffusion. This might happen even unintendedly. Companies should be aware that an early leaking of information about their R\&D investments could increase the probability to get 
imitated later. Therefore the cost and benefits of an open innovation regime should be balanced carefully.

Our study was limited by the response to the survey questions on the speed of imitation and information leakage, i.e. knowledge dissemination. In further studies, where larger databases might become available, it could be interesting to study the distribution of time-toimitation more closely and the link between imitation and profitability. Patents may decrease the likelihood of imitation but even when they fail to do so they might still provide enough time for the innovator to make the R\&D investment break even.

Furthermore, our empirical setup is limited by the cross-sectional nature of the data and the lack of more detailed project level information. Even though we instrument the leakage variable in a two-equation system, one point of concern might be possible endogeneity of the patent intensity variable. While we tried in the robustness test to work with long lags to make the exogeneity of the decision to patent more plausible, it would be preferred to exploit some clearly exogenous changes in the patent system that might drive variation in the choices to patent an invention or not. 


\section{References}

Amemiya, T. (1978). The Estimation of a Simultaneous Equation Generalized Probit Model. Econometrica, 46(5), 1193-1205.

Anton, J., \& Yao, D. (2004). Little patents and big secrets: Managing intellectual property. The Rand Journal of Economics, 35(1), 1-22.

Arora, A., Fosfuri, A., \& Gambardella, A. (2001). Markets for Technology and their Implications for Corporate Strategy. Industrial and Corporate Change, 10(2), 419-451.

Arrow, K. (1962), Economic Welfare and the Allocation of Resources for Invention, in: R.R. Nelson (ed.), The Rate and Direction of Inventive Activity, Princeton: Princeton University Press.

Audretsch, D., Coad, A., \& Segarra, A. (2014). Firm growth and innovation. Small Business Economics, 43(4), 743-749.

Audretsch, D., \& Feldman, M. (1996). R\&D Spillovers and the Geography of Innovation and Production. The American Economic Review, 86(3), 630-640.

Barrios, S., Gorg, H., \& Strobl, E. (2003). Explaining firms' export behaviour: R\&D, spillovers and the destination market. Oxford Bulletin of Economics and Statistics, 65(4), 475.

Bessen, J. (2005). Patents and the diffusion of technical information. Economics Letters, 86(1), 121-128.

Bessen, J., \& Meurer, M.. (2008). Patent failure: How judges, bureaucrats, and lawyers put innovators at risk. New Jersey: Princeton university press.

Bhattacharya, S., \& Guriev, S. (2006). Patents vs Trade Secrets: Knowledge Licensing and Spillover. Journal of the European Economic Association, 4(6), 1112-1147.

Boldrin, M., \& Levine, D. (2013). The Case Against Patents. Journal of Economic Perspectives, 27(1), 3-22. 
Coad, A., \& Rao, R. (2008). Innovation and firm growth in high-tech sectors: A quantile regression approach. Research Policy, 37(4), 633-648.

Cohen, W., Goto A., Nagata A., Nelson R., \& Walsh J. (2002). R\&D spillovers, patents and the incentives to innovate in Japan and the United States. Research Policy, 31(8), 13491367

Cohen, W., \& Klepper, S. (1996). A reprise of size and R \& D. The Economic Journal, 106(437), 925-951.

Cohen, W. M., \& Levinthal, D. A. (1989). Innovation and learning: the two faces of R \& D. The Economic Journal, 99(397), 569-596.

Czarnitzki, D., \& Kraft, K. (2010). On the profitability of innovative assets, Applied Economics 42(15), 1941-1953.

Czarnitzki, D., \& Kraft, K. (2012). Spillovers of innovation activities and their profitability. Oxford Economic Papers 64(2), 302-322.

Czarnitzki, D., \& O'Byrnes, N. (2007). R\&D, innovation and the impact on productivity in Flanders. Review of Business and Economics 52(2), 199-217.

Czarnitzki, D., \& Thorwarth, S. (2012). Productivity effects of basic research in low-tech and high-tech industries. Research Policy, 41(9), 1555-1564.

De Rassenfosse G., Palangkaraya A., \& Webster. E. (2016). Why do patents facilitate trade in technology? Testing the disclosure and appropriation effects. Research Policy, 45(7), $1326-1336$.

Diamond, A. (2003). Edwin Mansfield's contributions to the economics of technology. Research Policy 32(9), 1607-1617.

Fromer, J. (2009). Patent Disclosure. Iowa Law Review, 94(2), 539-606. 
Gans J., Hsu D., \& Stern S. (2008). The Impact of Uncertain Intellectual Property Rights on the Market for Ideas: Evidence from Patent Grant Delays. Management Science, 54(5), 982-997.

Goedhuys M., \& Veugelers, R. (2011). Innovation strategies, process and product innovations and growth: Firm-level evidence from Brazil. Structural Change and Economic Dynamics, 23(4), 516-529.

Greene, W. (2003). Econometric analysis (5th ed.). Upper Saddle River: Prentice Hall international.

Greene, W. (1998). Gender Economics Courses in Liberal Arts Colleges: Further Results. The Journal of Economic Education, 29(4), 291-300.

Griliches, Z., \& Mairesse J. ( 1984): "Productivity and R\&D at the firm level," in $R \& D$, Patents and Productivity, ed. by Z. Griliches, pp. 339-374. University of Chicago Press.

Hall, B. (1990): The manufacturing sector master file: 1959-1987, Discussion paper, National Bureau of Economic Research.

Heger, D., \& Zaby, A. K. (2018). Patent breadth as effective barrier to market entry. Economics of Innovation and New Technology, 27(2), 174-188.

Heller, M. (2008). The gridlock economy: How too much ownership wrecks markets, stops innovation, and costs lives. New York: Basic Books.

Horstmann, I., Macdonald, G., \& Slivinski, A. (1985). Patents as Information Transfer Mechanisms: To Patent or (Maybe) Not to Patent. Journal of Political Economy, 93(5), 837-858.

Jaffe, A., Trajtenberg, M., \& Henderson, R. (1993). Geographic localization of knowledge spillovers as evidenced by patent citations. Quarterly Journal of Economics, 108(3), 577-598. 
Lamoreaux, N., \& Sokoloff, K. (1999). Inventors, Firms, and the Market for Technology in the Late Nineteenth and Early Twentieth Centuries. In: Lamoreaux, N. (1999). Learning by doing in markets, firms, and countries (USA. National bureau of economic research. Conference reports). Chicago (Ill.): University of Chicago press.

Lee, L.F. (1992). Amemiya's generalized least squares and tests of overidentification in simultaneous equation models with qualitative or limited dependent variables. Econometric Reviews, 11(3), 319-328.

Lemley, M., \& Shapiro, C. (2007). Patent Holdup and Royalty Stacking*. Texas Law Review, 85(7), 2163-2173.

Levin, R., Cohen, W., \& Mowery, D. (1985). R \& D Appropriability, Opportunity, and Market Structure: New Evidence on Some Schumpeterian Hypotheses. The American Economic Review, 75(2), 20-24.

Macdonald S. (1998). What the patent system offers the small firm. Summary report, prepared for ESRC.

Machlup, F., \& Penrose, E. (1950). The Patent Controversy in the Nineteenth Century. The Journal of Economic History, 10(1), 1-29.

Mansfield, E. (1961). Technical change and the rate of imitation. Econometrica, 29(4), 741766.

Mansfield, E. (1980). Basic research and productivity increase in manufacturing. American Economic Review, 70(5), 863-873.

Mansfield, E. (1981). Composition of R and D Expenditures: Relationship to Size of Firm, Concentration, and Innovative Output. The Review of Economics and Statistics, 63(4), 610-615.

Mansfield, E. (1985). How Rapidly Does New Industrial Technology Leak Out? The Journal of Industrial Economics, 34(2), 217- 223. 
Mazzoleni, R., \& Nelson, R. (1998). The benefits and costs of strong patent protection: A contribution to the current debate. Research Policy, 27(3), 273-284

Menell, P., \& Meurer, M. (2013). Notice failure and notice externalities. Journal of Legal Analysis, 5(1), 1-59.

Newey, Whitney K. (1987). Efficient estimation of limited dependent variable models with endogenous explanatory variables. Journal of Econometrics, 36(3), 231-250.

OECD. (2015). Frascati Manual 2015: Guidelines for Collecting and Reporting Data on Research and Experimental Development - The Measurement of Scientific, Technological and Innovation Activities, OECD Publishing, Paris.

Oppenheim, C. (1998). How SMEs use the patent literature. Summary Report for the UK Economic and Social Research Council.

Ordover, J. (1991). A Patent System for Both Diffusion and Exclusion. Journal of Economic Perspectives, 5(1), 43-60.

Pedersen, P. (1970). Innovation Diffusion within and between National Urban Systems. Geographical Analysis, 2(3), 203-254.

Salomon, R., \& Jin, B. (2010). Do leading or lagging firms learn more from exporting? Strategic Management Journal, 31(10), 1088-1113

Stiglitz, J. (2008). Economic Foundations of Intellectual Property Rights. Duke Law Journal, 57(6), 1693-1724.

Teece, D. (1986). Profiting from technological innovation: Implications for integration, collaboration, licensing and public policy. Research Policy, 15(6), 285-305

Tang P., Adams J., Pare D. (2001) Patent protection of computer programmes submitted to the European commission. Directorate-General Enterprise.

Ziedonis, R. H. (2004). Don't Fence Me In: Fragmented Markets for Technology and the Patent Acquisition Strategies of Firms. Management Science, 50(6), 804-820. 


\section{Appendix}

Table 6: Sectoral distribution (423 observations)

\begin{tabular}{|c|l|c|c|}
\hline Sector & Sector description & N & R. Freq \\
\hline 1 & Food, beverage, tobacco & 22 & 0.05 \\
2 & Textile, clothing and leather industry & 30 & 0.07 \\
3 & Manufacture of cokes, chemicals, pharmaceuticals, rubber & 52 & 0.12 \\
& and plastic & 22 & 0.05 \\
4 & Manufacture basic and fabricated metal products & 28 & 0.07 \\
5 & Manufacture of electrical, electronic and optical products & 42 & 0.10 \\
6 & Manufacture, repair and installation of machinery, & & \\
& equipment, tools and transport & 66 & 0.16 \\
7 & Construction and civil engineering & 34 & 0.08 \\
8 & Wholesale & 89 & 0.21 \\
9 & Telecommunication, software design and programming, & & \\
& computer-consultancy and information services & 30 & 0.07 \\
10 & Architects and engineering, R\&D and management & & \\
11 & consulting & Residual sectors not mentioned elsewhere & 0.02 \\
\hline
\end{tabular}


Table 7: Bivariate Correlations for Estimation Sample of 423 Observations

\begin{tabular}{|c|c|c|c|c|c|c|c|c|c|c|c|}
\hline Pairwise correlation & 1 & 2 & 3 & 4 & 5 & 6 & 7 & 8 & 9 & 10 & 11 \\
\hline 1. IMITATION & 1 & & & & & & & & & & \\
\hline 2. R\&D DIFFUSION & 0.17 & 1 & & & & & & & & & \\
\hline 3. EXPORT & 0.19 & 0.06 & 1 & & & & & & & & \\
\hline 4. APPLIED R\&D \% & -0.02 & 0.02 & 0.02 & 1 & & & & & & & \\
\hline 5. DEVELOPMENT \% & 0.09 & -0.04 & 0.02 & -0.86 & 1 & & & & & & \\
\hline 6. R\&D INTENSITY & -0.05 & 0.11 & -0.06 & -0.00 & -0.01 & 1 & & & & & \\
\hline 7. EXTERNALR\&D & -0.04 & 0.07 & -0.09 & 0.02 & -0.02 & 0.55 & 1 & & & & \\
\hline 8. PATENT INTENSITY & -0.13 & 0.01 & -0.04 & -0.01 & 0.01 & 0.08 & -0.04 & 1 & & & \\
\hline 9. $\ln \mathrm{AGE}$ & 0.20 & 0.02 & 0.15 & -0.05 & 0.06 & -0.44 & -0.23 & -0.10 & 1 & & \\
\hline 10. InEMPLOYMENT & 0.21 & 0.00 & 0.27 & -0.13 & 0.17 & -0.49 & -0.27 & -0.21 & 0.56 & 1 & \\
\hline 11. EXT. CONSULT & 0.06 & 0.15 & 0.04 & -0.01 & -0.01 & 0.20 & 0.07 & -0.00 & -0.10 & 0.07 & 1 \\
\hline $\begin{array}{l}\text { 12. INDUSTRY R\&D } \\
\text { DIFFUSION }\end{array}$ & 0.13 & 0.32 & 0.16 & -0.01 & 0.03 & -0.10 & -0.04 & 0.07 & 0.17 & 0.12 & 0.02 \\
\hline
\end{tabular}

Notes: correlations in bold are significant at the 5\% level. 
KU LEUVEN

Faculty of Economics and Business Management, Strategy and Innovation (MSI)

Naamsestraat 69 bus 3535

3000 LEUVEN, Belgium

tel. + 3216326700

msi@econ.kuleuven.be

https://feb.kuleuven.be/research/MSI/ 